\title{
EXAMINING EMPLOYMENT QUALITY AMONG FEMALE IMMIGRANT TRAINEES IN TAIWAN
}

PROBLEMS

OF EDUCATION

IN THE $21^{\text {st }}$ CENTURY

Vol. 79, No. 6, 2021

993

\author{
Ya-Ling Wu \\ National Pingtung University of Science \& Technology, Taiwan \\ E-mail: karinnpust@gmail.com
}

\begin{abstract}
This study examined a proposed model of employment quality among female immigrants after their participation in vocational training in Taiwan, drawing on the developmental-contextual model of career development. It simultaneously tested the relationship between the distal contextual variable (i.e., perceived Taiwanese attitudes toward immigrant women (PTAs)), proximal contextual variables (i.e., vocational training experiences (VTEs) and social support (SS)), the individual-level variable (i.e., selfperceived employability (SPE)), and employment quality (EQ) in the model. A questionnaire survey was conducted among 447 female immigrant trainees who had worked for over 6 months after vocational training in Taiwan. The results supported the proposed model based on the developmental-contextual approach, which explained $56.9 \%$ of the variance in EQ. The results further revealed that PTAs positively affected SPE, VTES and SS. In turn, VTEs and SS positively directly and indirectly affected EQ through their impacts on SPE, and SPE positively influenced EQ. The three most important factors that determined the EQ of immigrant women who participated in vocational training were VTES, SPE, and PTAs.
\end{abstract}

Keywords: career development, employment quality, immigrant women, vocational training

\section{Introduction}

As the process of global and liberal economics has continuously called for flexibilization of the labor market, employment conditions such as income, job security and career prospects have changed tremendously. As a result, employment quality has become a human resource issue of worldwide interest (Burchell, et al., 2014). An increasing number of research demonstrates that employment quality is crucial for workers' well-being and sustainable career development (Berloffa et al., 2018; Burchell et al., 2014). Employment quality is a complex and multidimensional concept that involves a comprehensive evaluation of the interaction between workers and their working environment in the employment process (Almarshad, 2015; Burchell et al., 2014). It can therefore fully demonstrate the actual employment situation of workers and the dynamic relationship between workers' socioeconomic status and their labor market participation (Liu, 2011).

The labor market participation experiences of immigrant women are significantly different from those of immigrant men and native-born women. Due to the lack of labor marketability, urgent personal economic needs, and institutional ethnic and gender discrimination, immigrant women are usually located at the bottom of the labor market in host countries and become a marginalized and disadvantaged labor force with low work dignity and social status (Anthias et al., 2013). In fact, the employment of female immigrants improves their financial independence 
Ya-Ling WU. Examining employment quality among female immigrant trainees in Taiwan

PROBLEMS

OF EDUCATION IN THE $21^{\text {st }}$ CENTURY Vol. 79, No. 6,2021

994

and social integration in receiving countries and contributes to their family economic situation. To facilitate the employability of female immigrants and to improve their employment quality, involving female immigrants in vocational training to enter the labor market is one of the most important immigration policies in many countries (Kogan et al., 2018).

There is growing recognition that employment quality has a profound impact on the physical and psychological health of immigrant women (Berloffa et al., 2018). Compared with international migration in western developed areas, such as North America, Western Europe and Australia, just a small number of studies has focused on migration in Asia, although there has been a rapidly increasing number of immigrants in the region since the 1990s. Over the past two decades in Asia, Taiwan, like Japan and Korea, has had a stable growing number of female marriage immigrants from Mainland China and Southeast Asia (Tsai \& Lee, 2016), who represent around $2.0 \%$ of the total Taiwanese population (Ministry of the Interior, 2021).

Taiwan's rapid economic development has attracted women from less economically developed countries in Asia to marry Taiwanese men of low socioeconomic status through commercially arranged marriage in search of a prosperous life (Bélanger et al., 2010). Due to the economic disadvantages of most Taiwanese husbands, labor market participation has become the most urgent need for marriage immigrant women to improve the finances of their personal and natal families (Wu, 2014). Immigrant women's contribution to the Taiwanese labor market has been documented. In 2018, 67.9\% of immigrant women in Taiwan were employed in paid work (Ministry of the Interior, 2020), while the labor force participation rate of their Taiwanese counterparts was 58.2\% (Executive Yuan, 2021a); the employment rate of immigrant women therefore far exceeded that of Taiwanese women. The Taiwanese government has invested some resources to encourage immigrant women to take vocational training and improve their employability in response to their limited employment outcomes and relatively low work earnings and status (Ministry of the Interior, 2020). However, the employment achievement of immigrant women is still below that of their Taiwanese counterparts. In 2018, the average monthly work income of immigrant women was only $51.8 \%$ that of Taiwanese women (Executive Yuan, 2021b). Furthermore, immigrant women were overrepresented in unskilled and low-skilled occupations, with 33.3\% working as service and sales staff, $29.8 \%$ working as elementary laborers, and $19.2 \%$ working as machine operators. Among immigrant women, $32.9 \%$ worked in the manufacturing industry, $23.5 \%$ worked in the accommodation and catering industry, and $11.3 \%$ worked in the wholesale and retail industry (Ministry of the Interior, 2020). Overall, compared with Taiwanese counterparts, the employment quality among immigrant women is poor, which may cause social and economic disadvantages.

In Taiwan, since 2005, pre-job vocational training programs especially for immigrant women (VTPEIW) have been provided by public and private vocational training institutions with government funding. These programs in VTPEIWs average 300 hours over three months and provide training in personal services, basic computer skills, and cuisines. Around 22 VTPEIWs, which recruit about 660 trainees, have been offered every year. The training programs are provided free for female immigrant trainees, and trainees receive living allowances. To be eligible to attend the training, trainees must pass the basic Chinese reading and writing proficiency exam and attend an interview. However, the government only examines the employment experiences of female immigrant trainees through the follow-up investigation of their employment rate three months after the training (Ministry of Labor, 2020). The disregard of employment quality among female immigrant trainees might originate from rather limited national concerns about the employment of female immigrants and the fact that in Taiwan, commercially arranged marriage immigrant women are usually considered housewives instead of laborers (Tang \& Wang, 2011).

Although some employment research has focused on immigrant women in Taiwan, such as their work income and barriers to employment (e.g., Hsia, 2009), there is little contextualized 
and comprehensive understanding of employment quality among immigrant women after their participation in vocational training. Because employment quality is a key factor in immigrant women's well-being and career development (Berloffa et al., 2018), policies that cannot account for the employment quality of female immigrants are unlikely to facilitate their employment outcomes. This paper aims to fill this gap by exploring the essential factors that affect the employment quality of female immigrants who participate in vocational training in Taiwan.

\section{Literature Review and Hypotheses}

\section{Employment Quality}

Employment quality is a complex, multidimensional concept referring to the overall evaluation of various working conditions at the individual or aggregate (i.e., state or corporate) level (Berloffa et al., 2018). Although the definition and dimensions of employment quality vary across studies, it can be inferred that this concept revolves around laborers' health and well-being and can be a powerful predictor of labor mobility (Almarshad, 2015; Muñnoz de Bustillo et al., 2011). Since the present study aims to identify the factors that affect female immigrant trainees' personal subjective assessments of their working conditions and because using individual-level data can facilitate the analysis of specific employment experiences among subgroups of workers (Burchell et al., 2014), the perspective of the individual worker is adopted to measure employment quality in this study.

Employment is conceptualized by many different dimensions that are relevant to human needs in various ways. Existing studies focusing on individual-level employment quality usually encompass indicators such as earnings, workload (e.g., working hours), and insecurity (e.g., unemployment risk) (Berloffa et al., 2018). Although a match between educational qualifications and occupation is seldom emphasized in the literature on employment quality, skill mismatch is a widespread and increasing phenomenon in many host countries, especially for female immigrants (Wu, 2014). Thus, in this study, employment quality includes four dimensions that are considered crucial for understanding immigrant women's overall subjective evaluation of their working conditions: compensation, workload, security of employment, and match between educational qualifications and occupation.

\section{Developmental-Contextual Model of Career Development As the Study Framework}

The unique backgrounds of immigrant women display the complexity and diversity of their personal life experiences and their sociocultural contexts (Sadeghi, 2008). Employment quality is one of the most essential assessments and performances of career development (Berloffa et al., 2018 ). Thus, the study examined individual-level and contextual factors, as well as the interaction between them, to fully understand how the employment quality of immigrant women who participate in vocational training develops.

It is clear that neither a contextual perspective emphasizing the sources outside individuals nor an organismic perspective in terms of individual differences is appropriate to account for the complexity of career development (Vondracek \& Porfeli, 2008). The developmental-contextual model of career development, which is a comprehensive approach, combines both organismic and contextual perspectives. The approach conceptualizes development as the unfolding process of the interaction between a developing individual and multiple levels of context. This emphasizes three systems that interact in career development, including the individual, context, and dyadic individual-contextual interaction (Vondracek et al., 1986).

From this perspective, individual characteristics and activities influence not only individuals' own career development but also the contexts in which they operate. Namely, 
Ya-Ling WU. Examining employment quality among female immigrant trainees in Taiwan

PROBLEMS

OF EDUCATION

IN THE $21^{\text {st }}$ CENTURY Vol. 79, No. 6,202

996

individuals provide active contribution to their personal career development through their behaviors, which influence the contexts. Further, the contexts offer feedback according to individuals' actions, which impact individuals and their career development (Araújo \& do Céu Taveira, 2009).

Career development must be fully understood by placing the individual within the contexts that comprise various levels of systems that change interdependently. The contexts are defined by social, cultural, psychological, and physical parameters and include both proximal systems in which developing individuals directly participate and distal systems in which individuals cannot actively operate and that are out of their control. Additionally, the approach highlights the mutual and dynamic interaction between the individual and the contexts that results in individuals' career development. Since the individual and the contexts are mutually embedded, no single level of factors can function alone (Vondracek \& Porfeli, 2008).

\section{Factors Associated with Employment Quality}

The personal and contextual factors that would affect immigrant women's employment quality have been empirically explored infrequently in relation to one another or in combination. Drawing on the developmental-contextual model of career development, this study examined four factors that affect the employment quality (EQ) of female immigrants after their participation in vocational programs in Taiwan. The selected factors represent three domains of impact: selfperceived employability (SPE) as the individual-level factor, vocational training experiences (VTEs) and social support (SS) as the proximal contextual factors, and perceived Taiwanese attitudes toward immigrant women (PTAs) as the distal contextual factor.

PTAs. The attitudes of natives toward immigrants may affect immigrants' psychological health, employment, and well-being (Fernández et al., 2015; Tartakovsky et al., 2021). Although numerous studies have examined employment discrimination among immigrants in North America and Europe and there are potential influences of natives' attitudes toward immigrants on employment quality, little empirical research has explored the issue of marriage immigrant women in Asia.

Some studies have confirmed that there is a negative relationship between immigrants' perceived discrimination and their psychological well-being, which is moderated by the social support that they receive. Furthermore, immigrants' perceived discrimination has a negative impact on their level of received social support (e.g., Fernández et al., 2015; Jasinskaja-Lahti et al., 2006). Earlier studies have also shown that ex-prisoners who perceive a higher level of negative attitudes toward them tend to possess a lower level of perceived employability (Chui \& Cheng, 2013), and female graduates who suffer from negative attitudes due to their gender are more likely to have difficulty in their work adaptation (Moreau \& Leathwood, 2006).

In Taiwan, most immigrant women are from Mainland China and Southeastern Asia and arrive through commercially arranged marriages to seek a better life. These women usually give birth to descendants of their Taiwanese husbands and contribute to their natal families' finances. Thus, some Taiwanese people tend to stigmatize marriage immigrant women and their families. Specifically, immigrant women are believed to enter Taiwan only to make money and to cause social problems due to their family's low socioeconomic status. Consequently, some Taiwanese hold negative attitudes toward these women and even discriminate against them in work and daily life (Hsia, 2009; Yang et al., 2014). Based on these empirical findings, we expected that PTAs could be a predictor of the distal context of female immigrant trainees' EQ.

H2: VTEs are positively influenced by PTAs.

$\mathrm{H} 3$ : SS is positively influenced by PTAs.

H4: SPE is positively influenced by PTAs. 
VTEs. Individuals' employability is improved mainly through job-related learning (Scholarios et al., 2008). Some studies have suggested that the curriculum, instruction, interpersonal relationships, and career guidance of vocational training that meet female immigrant trainees' cultural needs can facilitate their employability (Sok et al., 2013; Wu, 2019). Previous studies have also revealed that immigrant women in Europe who participate in customized forms of training programs tend to have a higher level of employability and obtain well-paid jobs (Anthias et al., 2013). Moreover, Cohen-Goldner and Eckstein (2008) also found that in the 1990s, the more that vocational training programs met the needs of female immigrants from the Soviet Union to Israel, the more their working income increased. Budría and TelhadoPereira (2009) also have confirmed that high-quality training programs could improve trainees' job skills and access to jobs that match their education and training. Despite some general conclusions from these studies, the findings are usually case dependent. Thus, given the above empirical research, we expected that VTEs could represent a proximal contextual factor that would affect female immigrant trainees' EQ.

H5: SPE is positively influenced by VTEs.

H7: EQ is positively influenced by VTEs.

SS. Social support is the process by which individuals obtain emotional, instrumental, and informational assistance from recognized social networks. When focusing on immigrants, the role of social support must be examined in a multidimensional way. Migratory life involves immigrants' prior socialization in the homeland and new experiences in the host countries (Gellis, 2003). Thus, in this study, the support that immigrant women trainees receive includes support from their Taiwanese family and friends, their natal family, ethnic friends in Taiwan, and the government. Some research has suggested that social support networks with ethic groups and intimate families in host countries are an important mechanism for improving immigrants' career development, including employability (i.e., the accumulation of human capital and work adaptation) (Bolíbar, 2020) and employment quality (i.e., security of employment, work duties, and work earnings) (Debono \& Vassallo, 2020).

In Europe and Canada, immigrants pay attention to the social welfare resources (one type of social support from the government) that are available to them because these resources have much influence on their life adjustment in the host society. In most countries, immigration is essential for welfare issues (Barrett \& MacCarthy, 2008). Moreover, some studies have revealed that immigrant women who are provided with more social support (e.g., vocational training programs and settlement services) from the government tend to possess a higher level of employability (Wu, 2019) and obtain employment with higher income and more security (Liu, 2011). According to these empirical studies, this study expected that SS could be a predictor of the proximal settings of EQ in this study.

H6: SPE is positively influenced by SS.

H8: EQ is positively influenced by SS.

SPE. Employability is conceptualized as the ongoing fulfillment, acquisition, or creation of sustainable employment by applying individuals' knowledge, skills, and attitudes. Employability is a multifaceted construct with both objective and subjective elements (De Vos et al., 2011; Fugate et al., 2004). This study highlights individuals' self-perceived employability, which includes three dimensions: career identity, personal adaptability, and human and social capital (Fugate et al., 2004). Some studies have indicated that immigrant women's investment in their human capital, including language ability and training in host countries, could improve their income, job security, and job prospects (Kogan et al., 2018). Additionally, previous studies

$\mid$\begin{tabular}{l} 
PROBLEMS \\
OF EDUCATION \\
IN THE 21 1 st CENTURY \\
Vol. 79, No. 6, 2021 \\
\hline 997
\end{tabular} 


\section{Ya-Ling WU. Examining employment quality among female immigrant trainees in Taiwan}

PROBLEMS

OF EDUCATION

IN THE $21^{\text {st }}$ CENTURY Vol. 79, No. 6,202

have suggested that university graduates' career identity and personal adaptability are related to their job quality (i.e., pay, employment status, working hours, employment security) (GonzálezRomá et al., 2018). Building upon these findings, we aimed to test the relationship between the SPE and EQ of female immigrant trainees and formulate the following hypothesis:

H9: EQ is positively influenced by SPE.

In sum, according to the above results of the literature review, this study aimed to test the whole proposed theoretical model based on the developmental-contextual model of career development; and propose the hypothesis:

H1: the proposed theoretical model fits the sample data.

\section{The Aims of this Study and Research Model Hypotheses}

Given the above theoretical background, a theoretical model of EQ among female immigrant trainees in Taiwan and hypotheses are proposed in this study (see Figure 1). Thus, the goals of this study were two-fold. First, it attempted to examine the proposed theoretical model of employment quality among female immigrant trainees after their participation in vocational training in Taiwan by applying the developmental-contextual model of career development as the theoretical framework. Second, the study explored the relationship among the variables in the proposed model. Overall, this study aimed to test nine hypotheses, H1-H9as shown above.

\section{Figure 1}

\section{Proposed Hypothetical Model}

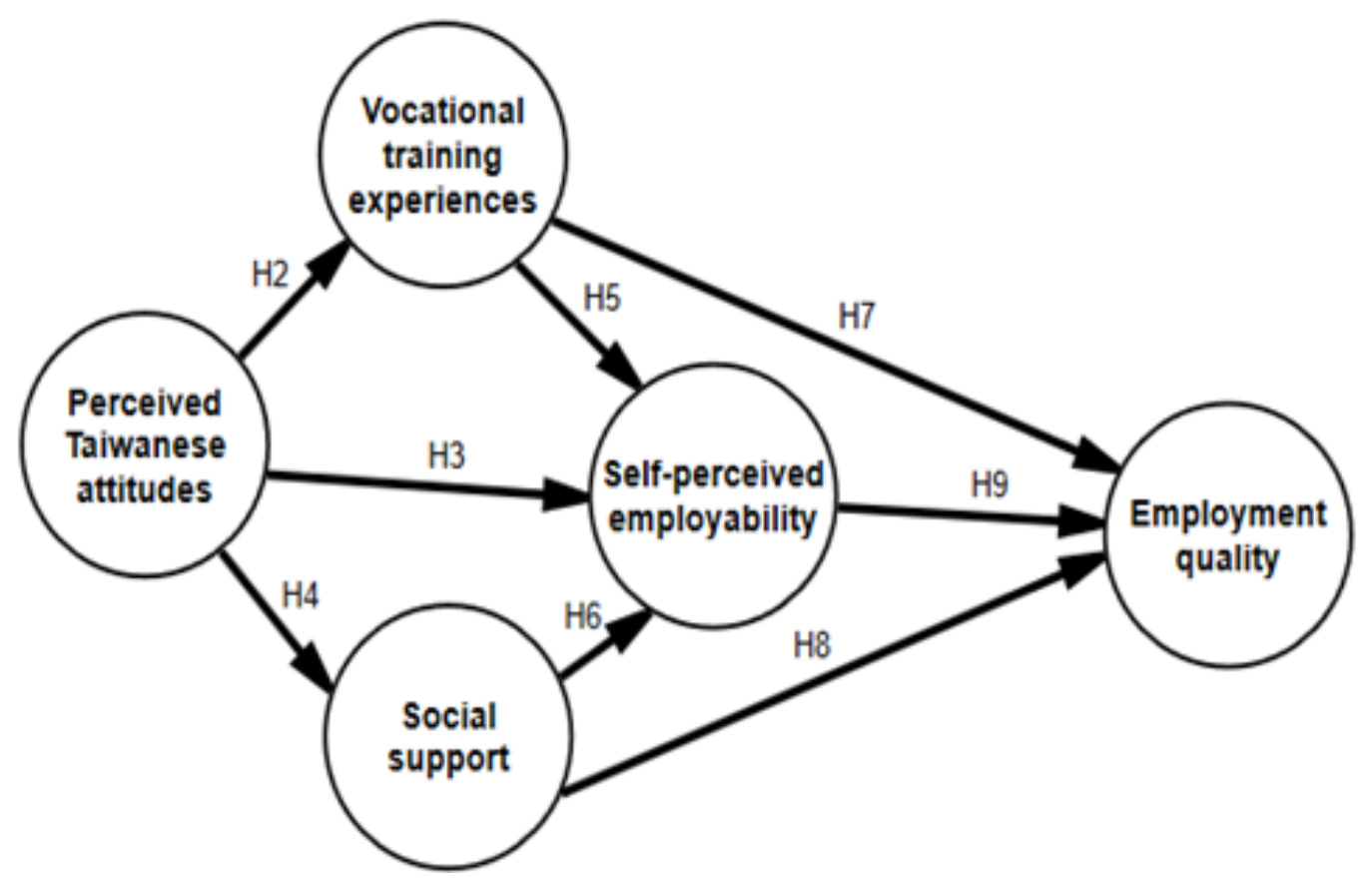

\section{Research Methodology}

\section{Sample Selection}

Data were collected by conducting a questionnaire survey. The research population consisted of marriage immigrant women who moved to Taiwan by marrying Taiwanese men. 
Additionally, the participants had successfully completed vocational training. At the time of their participation in the study, they had been employed in paid work for over 6 months after training. These participants were likely to have comprehensive employment experiences upon which they could reflect.

The study applied a stratified sampling method to select potential vocational training institutions that provided VTPEIWs based on the programs that they offered and their geographical locations. The types of job-related training programs comprised personal services, cuisines, computer skills, and others; the geographical locations covered the eastern, northern, central, and southern areas of Taiwan. In order to recruit more participants from each of the institutions, institutions in each of the regions were sampled based on the criterion that the institutions had more female immigrant trainees who had successfully finished vocation training and then obtained employment than other institutions. Consequently, 24 vocational training institutions were selected.

The sampled vocational training institutions were provided with the research proposal, and they all approved participation in this study. Because of the small number of target participants, all of the female immigrant women in every selected institution who met the above qualifications for research participation were invited to participate.

\section{Participants}

The questionnaires were administered to 497 immigrant women, and 447 of the questionnaires were usable (89.9\%). The ages of the participants ranged from 22 to 64 years $(M=$ $39.8, S D=9.72)$. The majority of the participants were from Mainland China $(58.4 \%), 28.0 \%$ were from Vietnam, 7.2\% were from Indonesia, and 6.5\% were from other countries. In their homeland, $42.0 \%$ of the participants held a senior high school degree, $32.9 \%$ held a junior high school degree, and $8.6 \%$ held an elementary school degree. Almost $73.3 \%$ of the participants were still married to Taiwanese husbands, and $14.6 \%$ were divorced. Of the sample, $84.0 \%$ had at least one child, and $63.1 \%$ had obtained Taiwanese identification. The participants had lived in Taiwan for an average of 10.9 years $(S D=6.1)$. They had, on average, 7.3 years $(S D=5.8)$ of job tenure in Taiwan and 2.3 years $(S D=3.4)$ of experience in their current job. Most of the participants had finished vocational training in personal services (78.7\%), 29.1\% in meal preparation, $10.7 \%$ in basic computer skills, and $5.4 \%$ in other types of training. Additionally, $43.2 \%$ had obtained technological certificates after completing training. Furthermore, $51.0 \%$ of the participants were employed full time and $49.0 \%$ were employed part time. A large portion of the women worked at only one job (91.3\%), while $8.1 \%$ worked at 2 jobs. Approximately $33.3 \%$ of the sample worked in the cosmetics industry, $21.3 \%$ in the accommodation and food service industry, $9.2 \%$ in the production industry, and $8.9 \%$ in the wholesale and retail industry. The majority of them worked as service and sales staff (76.5\%), and $13.4 \%$ of them worked as elementary laborers. Approximately $61.1 \%$ of the participants were employees, $12.1 \%$ were employers with employees, and $28.8 \%$ were self-employed without employees. Approximately $34.2 \%$ of the sample earned a monthly wage of US\$601-900, 33.3\% earned a monthly wage of US\$301-600, 14.8\% earned less than US\$300 monthly, and 11.2\% earned US\$901-1200 monthly. Approximately $35.6 \%$ of the participants worked over 41 hours weekly, $24.8 \%$ worked 31-40 hours weekly, and $15.2 \%$ worked less than 10 hours weekly.

Instructions for conducting the survey were provided for the vocational training institution staff to ensure the trustworthiness of the questionnaire survey. In the recruitment stage, the institution staff explained the research to the potential participants by phone and invited them to attend the study. Then, the female immigrants who were willing to attend the study came to the institutions and completed the anonymous self-report Chinese written questionnaires with the assistance of the institution staff. The participants got gift vouchers as reimbursement for participating in the research. 
Ya-Ling WU. Examining employment quality among female immigrant trainees in Taiwan

PROBLEMS

OF EDUCATION

IN THE $21^{\text {st }}$ CENTURY

Vol. 79, No. 6, 2021

1000

\section{Measures}

These scales of the questionnaire in this study were adapted primarily from various published sources. Each item was written in Chinese and was measured on a 5-point Likert scale ranging from $1=$ strongly disagree to $5=$ strongly agree.

$E Q$ was measured using a 4-item scale adapted from Burchell et al. (2014) and Berloffa et al. (2018) $(\alpha=0.93)$. The respondents indicated their perceptions of the degree to which their current work life met their needs. The scale included compensation, workload, employment security, and match between education and job (e.g., "I feel that there is a good match between my educational qualifications and my current job").

PTAs were assessed by a 3-item scale adapted from Tartakovsky et al. (2021) and Fernández et al. (2015) ( $\alpha=0.89)$. The scale assessed the respondents' perceptions of Taiwanese treatment toward immigrant women because of their female marriage immigrant status. The scale included work context, daily life context, and legal context (e.g., "I feel that we immigrant women in Taiwan have fair treatment in situations of possible promotion at work"). The higher the score, the more positive attitudes the respondents' perceived from Taiwanese people toward female marriage immigrants.

VTEs were tested utilizing a 4-item scale based on the work conducted by Budría \& Telhado-Pereira (2009) and $\mathrm{Wu}(2019)(\alpha=0.92)$ to assess the respondents' perception of the degree to which the vocational training programs met their needs. The scale included curriculum, instruction, interpersonal relationships, and guidance for certificate examinations (e.g., "The delivery of vocational training considered the life and learning habits of immigrant women").

SS was measured by a scale with 4 items adapted from Gellis (2003) and Fernández et al. (2015) $(\alpha=0.89)$ to assess the level of concerns and support that the respondents received when they needed help. The scale included support from Taiwanese family and friends, support from ethnic groups in Taiwan, support from natal family in the homeland, and support from the Taiwanese government (e.g., "My ethnic friends in Taiwan are willing to help me solve my problems").

SPE was measured using a 3 -item scale $(\alpha=0.90)$ based on the work of Fugate et al. (2004). The SPE scale tested the extent of the individuals' perceptions of their competencies required for maintaining or obtaining desirable employment appropriate to their qualification levels. Career identity, personal adaptability, and human and social capital were included in this scale (e.g., "The knowledge and skills that I possess are appropriate to the requirement of the work that I desire").

\section{Data Analysis}

Structural equation modeling (SEM) was applied to examine the proposed theoretical model and included paths. A hypothesized model was statistically tested to evaluate the degree to which it corresponded with the empirical data. SEM primarily comprises the measurement model and the structural model. The measurement model, which specifies the proposed relationship of the observed indicators to the constructs, is tested via confirmatory factor analysis (CFA). The structural model estimates all the hypothetical dependencies based on path analysis (Kline, 2015). In this research, the data were analyzed by applying AMOS 23.0 as the SEM software with the maximum likelihood (ML) method of estimation.

\section{Research Results}

Table 1 shows the descriptive statistics for each variable. All the variables had mean scores above the midpoint (3). Overall, the distribution of the mean scores for each variable was 
considered to be normal with skewness within \pm 3 (ranging from -0.29 to 0.15 ), kurtosis within IN THE $21^{\text {st }}$ CENTURY \pm 8 (ranging from -0.59 to 0.06 ), and the critical ratio value of multivariate kurtosis within 10 (8.97) (Kline, 2015). As illustrated in Table 1, the immigrant women generally perceived a slightly high level of positive attitudes from the Taiwanese, and they reported a moderately high level of social support that they could obtain when they needed help. Additionally, they reported that they possessed moderately high levels of perceived self-employability and employment quality.

Table 1

Descriptive Statistics of Constructs

\begin{tabular}{lcccc}
\hline Construct & $M$ & SD & Skewness & Kurtosis \\
\hline PTAs & 3.67 & .59 & .08 & .06 \\
\hline VTEs & 4.02 & .60 & -.29 & -.59 \\
\hline SS & 3.80 & .49 & -.02 & -.01 \\
\hline SPE & 3.97 & .49 & -.08 & -.04 \\
\hline EQ & 3.70 & .56 & .15 & -.54 \\
\hline
\end{tabular}

Convergent Validity and Discriminant Validity

The study examined convergent validity and discriminant validity to demonstrate the validity and reliability of the measurement model. The convergent validity of the indicators for each construct, which refers to the degree of which the observed indicators of a specific construct share a proportion of variance in common, is assessed by item reliability, the composite reliability of each construct, and the average variance extracted (AVE). All of the evidence shown in Table 2 indicates the satisfactory convergent validity of all the constructs in this study. The CFA results revealed good item reliability with significant loadings of all indicators $(p<.01)$ greater than 0.60 (Hair et al, 2018). The composite reliability and the AVE of every construct were over the thresholds of 0.7 and 0.5 , respectively (Hair et al., 2018). 
Ya-Ling WU. Examining employment quality among female immigrant trainees in Taiwan

PROBLEMS

OF EDUCATION IN THE $21^{\text {st }}$ CENTURY Vol. 79, No. 6, 2021

1002

Table 2

Convergent Validity of the Measurement Model

\begin{tabular}{|c|c|c|c|c|c|}
\hline \multirow[b]{2}{*}{ Constructs/ indicators } & \multicolumn{3}{|c|}{ Item reliability } & \multirow{2}{*}{$\begin{array}{l}\text { Composite } \\
\text { reliability }\end{array}$} & \multirow{2}{*}{$\begin{array}{l}\text { Average } \\
\text { variance } \\
\text { extractec }\end{array}$} \\
\hline & $\begin{array}{l}\text { Standardized } \\
\text { loading }\end{array}$ & $\begin{array}{c}\text { Standardized } \\
\text { errors }\end{array}$ & $t$-value & & \\
\hline PTAs & & & & 0.85 & 0.66 \\
\hline PTA1 & 0.85 & -- & -- & & \\
\hline PTA2 & 0.83 & 0.05 & $16.66^{* * *}$ & & \\
\hline PTA3 & 0.75 & 0.06 & $14.93^{* * *}$ & & \\
\hline VTEs & & & & 0.92 & 0.74 \\
\hline VTE1 & 0.73 & -- & -- & & \\
\hline VTE2 & 0.89 & 0.07 & $18.50^{* * *}$ & & \\
\hline VTE3 & 0.92 & 0.08 & $17.14^{* * *}$ & & \\
\hline VTE4 & 0.89 & 0.08 & $18.18^{* * *}$ & & \\
\hline SS & & & & 0.90 & 0.69 \\
\hline SS1 & 0.78 & - & -- & & \\
\hline SS2 & 0.80 & 0.06 & $20.49^{* * *}$ & & \\
\hline SS3 & 0.88 & 0.08 & $22.38^{* * *}$ & & \\
\hline SS4 & 0.96 & 0.08 & $20.72^{\star * \star}$ & & \\
\hline SPE & & & & 0.90 & 0.75 \\
\hline SPE1 & 0.86 & -- & -- & & \\
\hline SPE2 & 0.91 & 0.05 & $22.21^{* * *}$ & & \\
\hline SPE3 & 0.82 & 0.05 & $18.35^{\star * *}$ & & \\
\hline$E Q$ & & & & 0.88 & 0.65 \\
\hline EQ1 & 0.75 & -- & -- & & \\
\hline EQ2 & 0.77 & 0.06 & $14.90^{* * *}$ & & \\
\hline EQ3 & 0.87 & 0.06 & $17.14^{\star * \star}$ & & \\
\hline EQ4 & 0.83 & 0.06 & $18.18^{* * *}$ & & \\
\hline
\end{tabular}

Note: $* * * p<.001$

Discriminant validity, which assesses the extent to which constructs are distinct from one another, is measured by comparing the squared correlation between two constructs with either of their individual AVE estimates. The AVE estimates should be greater than the squared correlation estimate (Hair et al., 2018). The findings (see Table 3) indicated a high level of discriminant validity. Having assured convergent validity and discriminant validity, the constructs in the theoretical model were considered adequate. 
Table 3

Discriminant Validity of the Measurement Model

\begin{tabular}{|c|c|c|c|c|c|}
\hline Construct & PTAs & VTEs & SS & SPE & $E Q$ \\
\hline PTAs & .81 & & & & \\
\hline VTEs & .41 & .86 & & & \\
\hline SS & .26 & .11 & .83 & & \\
\hline SPE & .58 & .58 & .17 & .87 & \\
\hline$E Q$ & .45 & .63 & .25 & .69 & .81 \\
\hline
\end{tabular}

Note: Diagonals represent the square root of AVE. Other entries represent the correlations between constructs.

\section{Assessment of the Measurement Model}

Absolute fit measures, incremental fit measures, and parsimonious fit measures were applied to examine the overall fit of the measurement model with the five constructs (see Table 4) (Hair et al., 2018). Table 4 demonstrates all the model fit indices and the recommended level of acceptable fit. Except for the $\chi^{2}$ measure, the other values demonstrated acceptable goodnessof-fit statistics. The $\chi^{2}$ measure shows a pronounced tendency to reveal significant differences with increasing sample size, particularly in cases of sample sizes over 200 (Hair et al. 2018). This anomaly applies to this study of a sample of 447 . Additionally, the $\chi 2 / \mathrm{df}$ value in this study was within the acceptable range $(<3$, good). In sum, the proposed measurement model yielded a satisfactory fit to the empirical data.

\section{Table 4}

Goodness-of-Fit Measures for the Measurement Model

\begin{tabular}{|c|c|c|c|c|c|c|c|c|c|c|}
\hline \multirow{2}{*}{$\begin{array}{l}\text { Model fit } \\
\text { indices }\end{array}$} & \multicolumn{4}{|c|}{ Absolute fit measures } & \multicolumn{3}{|c|}{$\begin{array}{l}\text { Incremental fit } \\
\text { measures }\end{array}$} & \multicolumn{3}{|c|}{$\begin{array}{l}\text { Parsimonious fit } \\
\text { measures }\end{array}$} \\
\hline & $\chi^{2}$ & $\chi^{2} / \mathrm{df}$ & GFI & RMSEA & IFI & TLI & $\mathrm{CFI}$ & PGFI & PNFI & PCFI \\
\hline Values & $\begin{array}{l}1150.22 \\
P<.001\end{array}$ & 4.85 & 0.92 & 0.07 & 0.92 & 0.92 & 0.93 & 0.70 & 0.78 & 0.80 \\
\hline $\begin{array}{l}\text { Recom- } \\
\text { mended } \\
\text { criteria }\end{array}$ & $\begin{array}{l}\text { Non- } \\
\text { signifi- } \\
\text { cance }\end{array}$ & $\begin{array}{c}<3 \text { good } \\
<5 \text { accept- } \\
\text { able }\end{array}$ & $>0.90$ & $\begin{array}{c}<0.05 \text { good } \\
<0.08 \text { accept- } \\
\text { able }\end{array}$ & $>0.90$ & $>0.90$ & $>0.90$ & $>0.50$ & $>0.50$ & $>0.50$ \\
\hline
\end{tabular}

Note: $\chi 2$, Chi-square; $\chi 2$ df, the ratio of $\chi 2$ to its degree of freedom; GFI, goodness-of-fit index; RMSEA, rootmean-square error of approximation; IFI, incremental fit index; TLI, Tacker-Lewis index; CFI, comparative fit index; PGFI, parsimonious goodness-of-fit index; PNFI, parsimonious normal fit index; PCFI, parsimonious comparative fit index.

\section{Assessment of the Structural Model}

The fit of the theoretical structural model was assessed by utilizing absolute fit measures, incremental fit measures, and parsimonious fit measures (Hair et al., 2018). As shown in Table 5, except for the $\chi^{2}$ measure, the other selected goodness-of-fit measures showed reliable model fit. 
Ya-Ling WU. Examining employment quality among female immigrant trainees in Taiwan

PROBLEMS

OF EDUCATION

IN THE $21^{\text {st }}$ CENTURY

Vol. 79, No. 6, 2021

1004

Moreover, the $\chi 2 /$ df value in the present study was within the acceptable value ( $<5$, acceptable). In sum, the proposed structural model indicated a satisfactory fit to the empirical data.

Overall, the model explained $56.9 \%$ of the variance in the EQ of female immigrant trainees, supporting the hypothesis that the proposed theoretical model fits the sample data (H1). In other words, the proposed research model based on the developmental-contextual model of career development was effective in explaining the EQ of female immigrant trainees after their participation in vocational training in Taiwan.

Table 5

Goodness-of-Fit Measures for the Structural Model

\begin{tabular}{|c|c|c|c|c|c|c|c|c|c|c|}
\hline \multirow{2}{*}{ Model fit indices } & \multicolumn{4}{|c|}{ Absolute fit measures } & \multicolumn{3}{|c|}{$\begin{array}{l}\text { Incremental fit } \\
\text { measures }\end{array}$} & \multicolumn{3}{|c|}{$\begin{array}{l}\text { Parsimonious fit } \\
\text { measures }\end{array}$} \\
\hline & $\chi^{2}$ & $\chi^{2} / \mathrm{df}$ & GFI & RMSEA & $\mathrm{IFI}$ & TLI & CFI & PGFI & PNFI & PCFI \\
\hline Values & $\begin{array}{l}871.43 \\
p<.001\end{array}$ & 3.59 & 0.90 & 0.06 & 0.91 & 0.90 & 0.93 & 0.71 & 0.79 & 0.80 \\
\hline $\begin{array}{l}\text { Recommended } \\
\text { criteria }\end{array}$ & $\begin{array}{l}\text { Non- } \\
\text { signifi- } \\
\text { cance }\end{array}$ & $\begin{array}{c}<3 \text { good } \\
<5 \text { accept- } \\
\text { able }\end{array}$ & $>0.90$ & $\begin{array}{c}<0.05 \text { good } \\
<0.08 \text { accept- } \\
\text { able }\end{array}$ & $>0.90$ & $>0.90$ & $>0.90$ & $>0.50$ & $>0.50$ & $>0.50$ \\
\hline
\end{tabular}

Note: $\chi 2$, Chi-square; $\chi 2 / \mathrm{df}$, the ratio of $\chi 2$ to its degree of freedom; GFI, goodness-of-fit index; RMSEA, rootmean-square error of approximation; IFI, incremental fit index; TLI, Tacker-Lewis index; CFI, comparative fit index; PGFI, parsimonious goodness-of-fit index; PNFI, parsimonious normal fit index; PCFI, parsimonious comparative fit index.

Figure 2 shows the examined path coefficients of the proposed theoretical model. All eight hypotheses of the relationships between the variables were supported (H2-H5 and $\mathrm{H} 7$ at the .01 significance level; $\mathrm{H} 6$ and $\mathrm{H} 8$ at the .05 significance level; H2: PTAs $\rightarrow$ VTEs, $\beta=0.40$, $t$-value $=9.10 ; \mathrm{H} 3: \mathrm{PTAs} \rightarrow \mathrm{SPE}, \beta=0.40, t$-value $=9.10 ; \mathrm{H} 4: \mathrm{PTAs} \rightarrow \mathrm{SS}, \beta=0.25, t$-value $=9.10$; $\mathrm{H} 5:$ VTEs $\rightarrow \mathrm{SPE}, \beta=0.34, t$-value $=8.23$; H6: SS $\rightarrow \mathrm{SPE}, \beta=0.08, t$-value $=2.41 ; \mathrm{H} 7: \mathrm{VTEs} \rightarrow \mathrm{EQ}$, $\beta=0.41, t$-value $=8.23 ; \mathrm{H} 8: \mathrm{SS} \rightarrow \mathrm{EQ}, \beta=0.07, t$-value $=2.41 ; \mathrm{H} 9: \mathrm{SPE} \rightarrow \mathrm{EQ}, \beta=0.49, t$-value $=7.76$ ).

Moreover, the variance of four endogenous variables in the proposed model was assessed. EQ was significantly determined by SPE, VTEs, SS, and PTAs, which resulted in an $R^{2}$ of 0.569 . SPE was determined by VTEs, SS, and PTAs with an $R^{2}$ of 0.483 . VTEs and SS were both determined by PTAs, which resulted in an $R^{2}$ of 0.157 , and 0.063 , respectively.

Regardingthe effectsofindependent variablesonEQ offemaleimmigranttraineesafter their participation in vocational training, as shown in Fig. 2, VTEs and SS had both direct and indirect influences on EQ through their effects on SPE. Additionally, SPE directly affected EQ, and PTAs indirectly affectedEQ. Ofall the independentvariables, the totaleffectofVTEsonfemaleimmigrant trainees' $E Q$ was the greatest (estimate $=.41+.34 \times .49=0.538$ ), followed by SPE (estimates $=0.486$ ), PTAs (estimates $=.40 \times .41+.40 \times .34 \times .49+.40 \times .49+.25 \times .07+.25 \times .08 \times .49=0.436$ ), and SS (estimates $=.07+.08 \times .49=0.113$ ). In sum, in this study, the three most important factors that determined the EQ of immigrant women who participated in vocational training were VTEs, SPE, and PTAs. 


\section{Figure 2}

Results of Testing the Proposed Theoretical Model

PROBLEMS

OF EDUCATION

IN THE $21^{\text {st }}$ CENTURY

Vol. 79 , No. 6,2021

1005

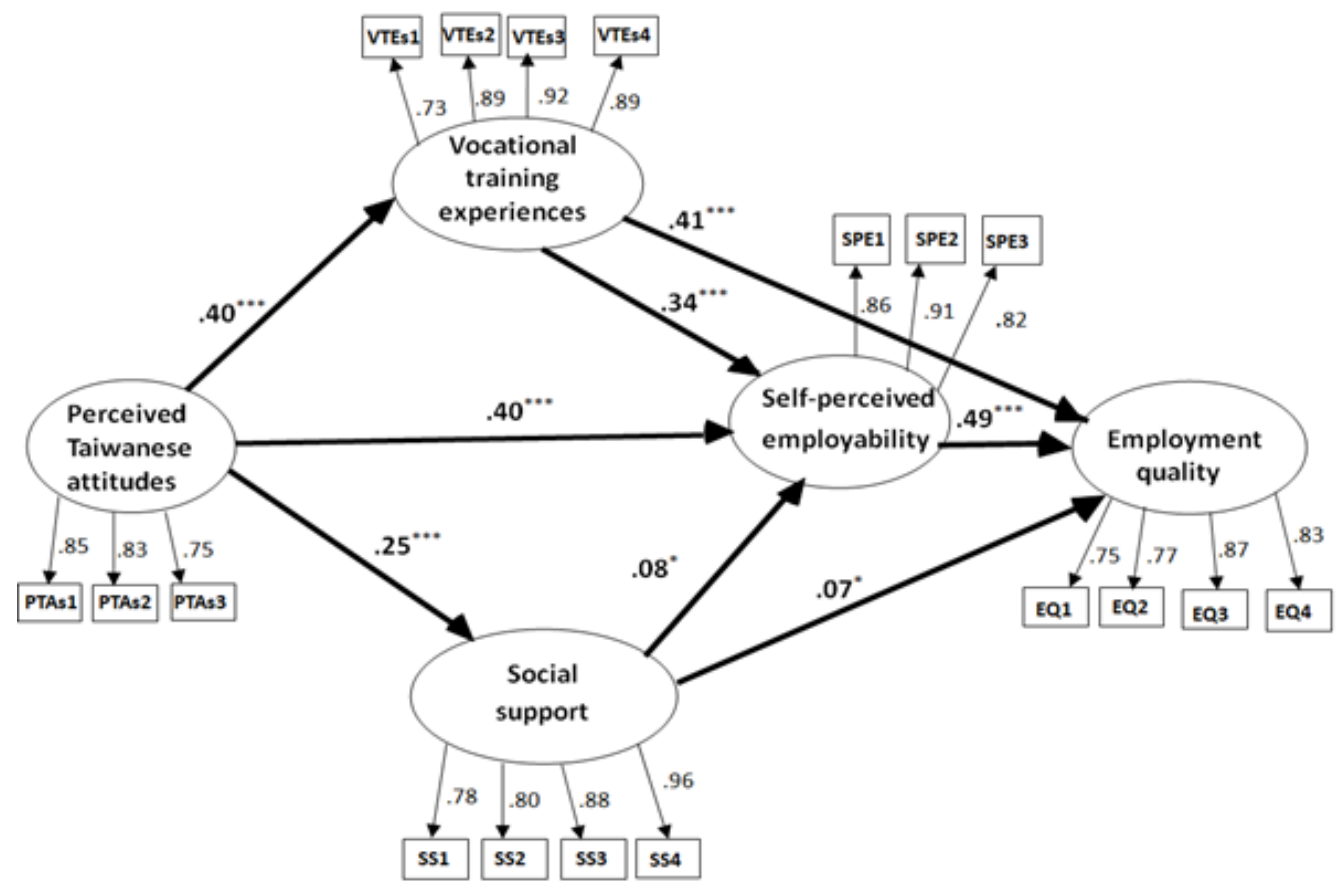

Note: $* * * p<.001 ; * p<.05$

\section{Discussion}

The empirical results supported the suitability of the research model according to the developmental-contextual model of career development for explaining EQ among female immigrant trainees after their participation in vocational training in Taiwan. The results further revealed that PTAs, a distal contextual factor, positively affected VTEs and SS at the proximal contextual level and SPE at the individual level. VTEs and SS, in turn, positively directly and indirectly affected EQ through their impacts on SPE, which in turn positively affected EQ.

The finding that VETs, as one of the proximal contextual factors, had the greatest positive direct and indirect impact on the EQ of female immigrants taking vocational training in Taiwan confirms the significance of vocational training that responds to the learning needs of female immigrant trainees in facilitating the sustainable employment development of this disadvantaged minority group. In Taiwan, most immigrant women tend to participate in jobrelated training not only to improve their employability and obtain meaningful employment but also to obtain professional certificates to compensate for their low-education backgrounds and to optimize themselves in the eyes of the host society. Consequently, immigrant women usually become the targets and victims of vocational training markets that cannot take into account their unique needs (Wu, 2014).

Although the access to vocational training is important, it is more essential to focus on the achievement of training. Generally training in itself does not guarantee satisfactory employment (Anthias et al., 2013). Nevertheless, in Taiwan, the primary goal of most vocational training institutions seems to be to save money and assimilate female immigrant trainees rather than responding to the barriers that they may experience in vocational training (Wu, 2014). For immigrant women, participating in vocational training may be a frustrating and discouraging 
Ya-Ling WU. Examining employment quality among female immigrant trainees in Taiwan

PROBLEMS

OF EDUCATION IN THE $21^{\text {st }}$ CENTURY Vol. 79, No. 6,2021

1006

process when the diversity of their needs and concerns is not acknowledged (Lior \& Wismer, 2003). Although immigrant women's needs and obstacles to training have been studied in Taiwan, resources and mechanisms for implementing vocational training for immigrant women have seldom been adequate to respond to their needs. Thus, access to proper and high-quality job-related training has been identified as an issue for immigrant women in Taiwan (Wu, 2014). Vocational training in isolation certainly cannot improve female immigrants' employment problems. However, job-related training that is integrated with the needs of immigrant women as part of an integrated strategy for creating sustainable employment development would remove the obstacles that prevent immigrant women from accessing the occupations they need (Lior \& Wismer, 2003).

SPE, an individual-level factor, represented another essential determinant that positively and directly contributed to the EQ of female immigrant trainees in Taiwan. The results empirically supported the suggestion that employability may even be an essential predictor of an individual's employment quality. Thus, possessing a certain level of employability with career identity, personal adaptability, and human and social capital is necessary for immigrant women to function well in the contemporary labor market (De Vos et al., 2011).

PTAs, at the distal contextual level, played a significant role in positively and indirectly affecting the EQ of female immigrant trainees in Taiwan through their influence on the factors of proximal contexts and the individual. Moreover, the results suggest that in the proposed model, PTAs were the most important factors affecting the SPE of female immigrant trainees. This indicates the significance of natives' attitudes toward immigrant women on the employment development of this ethnic minority group in Taiwan. Compared to the general public, the employment of disadvantaged individuals, such as immigrants and ethnic minorities, is more likely to be affected by the majority's negative attitudes toward job search, work adaptation, work advancement, income and security (Fernández et al., 2015). In Taiwan, immigrant women tend to be vulnerable to the public's negative treatment and even discrimination due to their special status as marriage immigrants as well as their race and gender (Yang et al., 2014). The mean score of PTAs, as shown in Table 3, indicated that the female immigrant trainees in this study perceived slightly positive attitudes from the host society $(M=3.67>3.0, S D=.59)$. However, previous studies have revealed the existence of some Taiwanese discrimination against immigrant women in Taiwan (e.g., Hsia, 2009), and positive attitudes do not mean a lack of unfair behaviour. Therefore, the effect of PTAs on female immigrant trainees' employability and employment quality must be carefully addressed.

Although, as expected, the findings indicated that SS, as the proximal contextual factor, had positive direct and indirect impacts on immigrant women's EQ vis-à-vis its effect on SPE, the total impact of SS on EQ was smaller than that of the other factors in this study (estimate $=0.113$ ). For marriage immigrant women, access to and the establishment of social support networks can be difficult in the host country, especially if the society of settlement is not receptive to them. Furthermore, the ethnic and location composition of their support networks may vary (Jasinskaja-Lahti et al., 2006). Although previous studies have suggested that social support is beneficial to immigrants' employment, membership and size are essential elements of social support. The literature has shown that support from their husbands and their families is an essential factor that influences marriage immigrant women's employment (Lin \& Huang, 2007). Larger networks may have more potential to provide support, but they are more likely to increase conflict and negative effects on immigrants' lives due to the pressure, responsibility and restrictions originating from the intense involvement and ties among certain social networks (Gellis, 2003). Additionally, high-density ethnic group networks may centralize the immigrant labor force within ethnic occupational niches, and the exchange of solidarity and information through social networks keeps migrants in occupational positions similar to those held by other ethnic group members (Bolíbar, 2020). 
Additionally, the availability of ethnic community support in the host country can work as a buffer to improve the negative employment experiences of immigrants only when they suffer from discrimination (Jasinskaja-Lahti et al., 2006). Thus, each type and size of social support network may have a particular contribution to marriage immigrant women's employment quality. In this study, SS was assessed by a combination of support from different members and locations, which may lead to a mixed impact of these SS on marriage immigrant women's EQ. Namely, the exact contribution of the separate sources of these SS to these women's EQ could be offset. Nevertheless, it is encouraging that in this study, SS was empirically proven to contribute to EQ among female immigrant trainees.

\section{Conclusions and Implications}

The results of the study supported the proposed model based on the developmentalcontextual approach, which explained $56.9 \%$ of the variance in EQ. The results further revealed that PTAs positively affected SPE, VTEs and SS. In turn, VTEs and SS positively directly and indirectly affected EQ through their impacts on SPE, and SPE positively influenced EQ. The three most important factors that determined the EQ of immigrant women who participated in vocational training were VTEs, SPE, and PTAs. Namely, this research demonstrates an important extension of early studies on employment quality by confirming the applicability of the developmental-contextual model of career development to explaining EQ among female marriage immigrant trainees in Taiwan and recognizes the essential factors that influence the EQ of the ethnic minority group. These results have implications for strategies and policies to improve EQ among female immigrant trainees.

Female immigrant trainees could be offered job-related training programs in a culturally responsive way that can meet their training needs and solve their training problems. Specifically, the curriculum and instruction should be integrated with these women's cultural backgrounds, and instructors should understand and treasure these trainees' diverse experiences and assist them in their career development. Furthermore, female immigrant trainees should be provided with social support interventions during vocational training to make these trainees aware of the importance of and access to social support. Additionally, although this is never easy to achieve, the Taiwanese government could build more immigrant-friendly environments to facilitate the Taiwanese people's positive attitudes toward immigrant women. Specifically, the government could produce legislation to protect immigrant women from negative treatment at work and in daily life to facilitate their employment development.

To understand the significance of social support, future studies could distinguish the effect of separate sources of social support with different members and sizes on female immigrant trainees' EQ. Moreover, it is essential to highlight the importance of the cultural contexts in which female immigrant trainees have lived. Future research may focus on crosscultural comparisons of employment quality among immigrant women from different cultural backgrounds.

\section{References}

Anthias, F., Cederberg, M., Barber, T., \& Ayres, R. (2013). Welfare regimes, markets and policies: The experiences of migrant women. In F. Anthias, M. Kontos, \& M. Morokvasic-Müller (Eds.), Paradoxes of integration: Female migrants in Europe (pp. 37-58). Springer.

Araújo, A. M., \& do Céu Taveira, M. (2009). Study of career development in children from a developmental-contextual perspective. European Journal of Education and Psychology, 2(1), 49-67. https://doi.org/10.30552/ejep.v2i1.19

\author{
PROBLEMS \\ OF EDUCATION \\ IN THE $21^{\text {st }}$ CENTURY \\ Vol. 79, No. 6, 2021 \\ 1007
}


Ya-Ling WU. Examining employment quality among female immigrant trainees in Taiwan

PROBLEMS

OF EDUCATION

IN THE $21^{\text {st }}$ CENTURY Vol. 79, No. 6,2021

1008

Barrett, A., \& MacCarthy, Y. (2008). Immigrants and welfare programmes: Exploring the interactions between immigrant characteristics, immigrant welfare dependence, and welfare policy. Oxford Review of Economic Policy, 24(3), 542-559. https://doi.org/10.1093/oxrep/grn026

Bélanger, D., Lee, H., \& Wang, H. (2010). Ethnic diversity and statistics in East Asia: Foreign brides' surveys in Taiwan and South Korea. Ethnic and Racial Studies, 33(6), 1108-1130. https://doi.org/10.1080/01419870903427507

Berloffa, G., Matteazzi, E., Mazzolini, G., Sandor, A., \& Villa, P. (2018). How can young people's employment quality be assessed dynamically. In D. J. Behavro, \& N. Gilbert (Eds.), Youth labor in transition (pp.237-270). Oxford University Press.

Bolíbar, M. (2020). Social capital, human capital and ethnic occupational niches: An analysis of ethnic and gender inequalities in the Spanish labour market. Palgrave Communications, 6(1), 1-9. https://doi.org/10.1057/s41599-020-0397-4

Budría, S., \& Telhado-Pereira, P. (2009). The contribution of vocational training to employment, jobrelated skills and productivity: evidence from Madeira. International Journal of Training and Development, 13(1), 53-72.

Burchell, B., Sehnbruch, K., Piasna, A., \& Agloni, N. (2014). The quality of employment and decent work: Definitions, methodologies, and ongoing debates. Cambridge Journal of Economics, 38(2), 459-477. http://doi.org/10.1093/cje/bet067

Chui, W. H., \& Cheng, K. K. (2013). The mark of an ex-prisoner: Perceived discrimination and selfstigma of young men after prison in Hong Kong. Deviant Behavior, 34(8), 671-684. https://doi.or $\mathrm{g} / 10.1080 / 01639625.2013 .766532$

Cohen-Goldner, S., \& Eckstein, Z. (2008). Labor mobility of immigrants: Training, experience, language, and opportunities. International Economic Review, 49(3), 837872. https://doi.org/10.1111/j.1468-2354.2008.00499.x

De Vos, A., De Hauw, S., \& Van der Heijden, B. I. (2011). Competency development and career success: The mediating role of employability. Journal of Vocational Behavior, 79(2), 438447. https://doi.org/10.1016/j.jvb.2011.05.010

Debono, M., \& Vassallo, M. T. (2020). Predictors of employment outcomes among Filipino workers in Malta. Science Journal of the Malta Chamber of Scientists, 8, 16-31. https://doi.org/10.7423/XJENZA.2020.1.02

Executive Yuan (2021a). The labor force participation rate of Taiwanese females. https://win.dgbas.gov. tw/dgbas04/bc4/timeser/comuse_f.asp

Executive Yuan (2021b). The salary of Taiwanese females. https://earnings.dgbas.gov.tw/query payroll_C.aspx?mp=4

Fernández, I., Silván-Ferrero, P., Molero, F., Gaviria, E., \& García-Ael, C. (2015). Perceived discrimination and well-being in Romanian immigrants: The role of social support. Journal of Happiness Studies, 16(4), 857-870. https://doi.org/10.1007/s10902-014-9537-0

Fugate, M., Kinicki, A. J., \& Ashforth, B. E. (2004). Employability: A psycho-social construct, its dimensions, and applications. Journal of Vocational Behavior, 65(1), 14-38. https://doi.org/10.1016/j.jvb.2003.10.005

Gellis, Z. D. (2003). Kin and nonkin social supports in a community sample of Vietnamese immigrants. Social Work, 48(2), 248-258. https://doi.org/10.1093/sw/48.2.248

González-Romá, V., Gamboa, J. P., \& Peiró, J. M. (2018). University graduates’ employability, employment status, and job quality. Journal of Career Development, 45(2), 132-149. https://doi.org/10.1177\%2F0894845316671607

Hair, J. F., Babin, B. J., Anderson, R. E., \& Black, W. C. (2018). Multivariate Data Analysis (8 ${ }^{\text {th }}$ ed). Prentice-Hall International.

Hsia, L. C. (2009). The study on the employment of foreign spouses. Ministry of the Interior.

Jasinskaja-Lahti, I., Liebkind, K., Jaakkola, M., \& Reuter, A. (2006). Perceived discrimination, social support networks, and psychological well-being among three immigrant groups. Journal of CrossCultural Psychology, 37(3), 293-311. https://doi.org/10.1177/0022022106286925

Kline, R. B. (2015). Principles and practice of structural equation modeling. Guilford Press.

Kogan, I., Shen, J., \& Siegert, M. (2018). What makes a satisfied immigrant? Host-country characteristics and immigrants' life satisfaction in eighteen European countries. Journal of Happiness Studies, 19(6), 1783-1809. https://doi.org/10.1007/s10902-017-9896-4 
Lin, L. H., \& Hung, C. H. (2007). Vietnamese women immigrants' life adaptation, social support, and depression. The Journal of Nursing Research, 15(4), 243-254.

Lior, K., \& Wismer, S. (2003). Still shopping for training: Women, training and livelihoods. In M. G. Cohen (Ed.), Training the excluded for work (pp.214-229). UBC Press.

Liu, C. Y. (2011). Employment concentration and job quality for low-skilled. Latino immigrants. Journal of Urban Affairs, 33(2), 117-142. https://doi.org/10.1111/j.1467-9906.2010.00534.x

Ministry of Labor (2020). Statistics of vocational training programs in 2019. Ministry of the Interior.

Ministry of the Interior (2020). The survey on the life needs of new immigrants. Ministry of the Interior. https://ws.moi.gov.tw/001/Upload/OldFile/news_file

Ministry of the Interior (2021). The number of Immigrants in Taiwan. https://www.immigration.gov.tw/ ct.asp?xItem $=1348481 \&$ ctNode $=29699 \& \mathrm{mp}=1$

Moreau, M. P., \& Leathwood, C. (2006). Graduates' employment and the discourse of employability: A critical analysis. Journal of Education and Work, 19(4), 305-324. https://doi.org/10.1080/13639080600867083

Muñoz de Bustillo, R., Fernández-Macías, E. Esteve, F., \& Antón, J-I. (2011). E pluribus unum? A critical survey of job quality indicators. Socio-Economic Review, 9(3), $447-$ 475. https://doi.org/10.1093/ser/mwr005

Sadeghi, S. (2008). Gender, culture and learning: Iran immigrant women in Canadian higher education. International Journal of Lifelong Education, 27(2), 217-234. https://doi.org/10.1080/02601370801936382

Sok, J., Blomme, R., \& Tromp, D. (2013). The use of the psychological contract to explain selfperceived employability. International Journal of Hospitality Management, 34, 274-284. https://doi.org/10.1016/j.ijhm.2013.03.008

Scholarios, D., Van der Heijden, B. I., Van der Schoot, E., Bozionelos, N., Epitropaki, O., Jedrzejowicz, P., Knauth, P., Marzec, I., Mikkelsen, A., \& Van der Heijde, C. M. (2008). Employability and the psychological contract in European ICT sector SMEs. The International Journal of Human Resource Management, 19(6), 1035-1055.

Tang, A. W., \& Wang, H. Z. (2011). From victims of domestic violence to determined independent women: How Vietnamese immigrant spouses negotiate Taiwan's patriarchy family system. Women's Studies International Journal Forum, 34(5), 430-440. https://doi.org/10.1016/j.wsif.2011.06.005

Tartakovsky, E., Patrakov, E., \& Nikulina, M. (2021) Is emigration worth the trouble? Satisfaction with life, group identifications, perceived discrimination, and socio-economic status of immigrants and stayers. International Journal of Intercultural Relations, 80, 195-205.

Tsai, T. I., \& Lee, S. Y. D. (2016). Health literacy as the missing link in the provision of immigrant health care: A qualitative study of Southeast Asian immigrant women in Taiwan. International Journal of Nursing Studies, 54, 65-74. https://doi.org/10.1016/j.ijnurstu.2015.03.021

Vondracek, F. W., \& Porfeli, E. J. (2008). Social contexts for career guidance throughout the worldDevelopmental-contextual perspectives on career across the lifespan. In J. A. Athanasou, \& R. Van Esbroeck (Eds.), International handbook of career guidance (pp. 209-225). Springer.

Vondracek, F.W., Lerner, R. M., \& Schulelberg, J. E. (1986). Career Development: A Life-span Developmental Approach. Erlbaum.

Wu, Y. L. (2014). A socio-cultural approach to understanding the learning experiences of vocational training among Vietnamese immigrant women in Taiwan. Women's Studies International Forum, 44, 80-88. https://doi.org/10.1016/j.wsif.2013.10.004

Wu, Y. L. (2019). Examining self-perceived employability among immigrant women participating in vocational training in Taiwan. International Journal of Training and Development, 23(4), 313 327. https://doi.org/10.1111/ijtd.12164

Yang, H. J., Wu, J. Y., Huang, S. S., Lien, M. H., \& Lee, T. S. H. (2014). Perceived discrimination, family functioning, and depressive symptoms among immigrant women in Taiwan. Archives of Women's Mental Health, 17(5), 359-366. https://doi.org/10.1007/s00737-013-0401-8 
Ya-Ling WU. Examining employment quality among female immigrant trainees in Taiwan

PROBLEMS

OF EDUCATION

IN THE $21^{\text {st }}$ CENTURY
Vol. 79, No. 6,2021

Vol. 79 , No. 6,2021

Received: September 28, 2021

Accepted: November 30, 2021

Cite as: Wu, Y.-L. (2021). Examining employment quality among female immigrant trainees in Taiwan. Problems of Education in the 21 $1^{\text {st }}$ Century, 79(6), 993-1010. https://doi.org/10.33225/pec/21.79.993

Ya-Ling Wu Graduate Institute of Technological and Vocational Education, National Pingtung University of Science \& Technology, Taiwan.

E-mail: karinnpust@gmail.com

ORCID: https://orcid.org/0000-0002-0591-1351 